\title{
Family Friendly Entrepreneurship: New Business Formation in Family Spaces
}

\author{
Carol Ekinsmyth
}

Carol Ekinsmyth, Department of Geography, University of Portsmouth, UK

(carol.ekinsmyth@port.ac.uk)

\begin{abstract}
Seventy three per cent of UK enterprises have no employees and seventeen per cent of these are managed solely by women (GEM UK Data 2005). UK female entrepreneurship is thus a significant economic phenomenon and it is increasing, especially in rural areas. Suggestions are that women's businesses are different to men's (Ahl 2006, Hanson 2003, Hanson and Blake 2004) in terms of their nature, location, type and the way that business is done. Limited empirical investigation has been undertaken, especially within geography (Hanson 2003). In addition, it has been argued that women's participation in selfemployment generally, is under-theorised (Blake, 2006; Ahl, 2006; Lewis 2006). Buzar et al (2005) identify the need to consider within this, the social construction of gender, time, space, economy and culture. This paper aims to advance knowledge and understanding of both the characteristics of female businesses and the coordinates and circumstances of female entrepreneurship. This paper will investigate the nature, dynamics, networks and locations of the new businesses (started up within the past five years) of thirty women entrepreneurs all of whom are mothers and most of whom work at home. Two different types of new work/economic space will be examined. The first, the work locations of this economic activity, are a key defining feature of these businesses - they are typically the kitchens, bedroom and garages of the entrepreneurs' family homes within the spaces of family life. An understanding of such enterprises is assisted by adopting a household-level, work-life reconciliation perspective (Jarvis 2005, Moen and Sweet 2004). The second new economic space reported in this paper will be the typical spaces of networking and marketing which often take place in electronic space, particularly the social networking sites (and especially female social and business networking, and mothers' networking internet sites that have become so popular in the past five years or so. Thus this paper will focus on new spaces of work and new ways of doing business.
\end{abstract}

Keywords: women entrepreneurship, business location, spaces of networking

\section{Introduction}

This empirically based discussion reconceptualises the boundaries conventionally placed around two foci in economic geography, the spaces of production, and the identity of key players. Concentrating on middle-class mothers who have small businesses, the paper is able to advance understanding about both the gendering of entrepreneurship and, the home/domestic neighbourhood as a location of business formation. Specifically, the paper moves forward debates about entrepreneurship as one option available to professional women who experience, suffer or choose fractured careers as a result of motherhood priorities. The arguments here call for an agenda that takes seriously new, entrepreneurial economic actors who are embedded in domestic spaces, a type of business owner who belongs to a growing and significant phenomenon in countries throughout the world (Harding 2006, McClelland et al 2005).

In contrast to research designs that implicitly assume female entrepreneurs to be an internally undifferentiated group, this research has taken the innovative approach of 
restricting focus to a highly specific group of professional-class, mostly degreeeducated mothers. This acknowledges the growing appreciation amongst scholars that childbirth is the point at which the lives and careers of professional women and men diverge (Bradley, 2007). Through this focus, the research is able to advance understandings of the ways in which the boundaries of business formation are spatially extended into the home, extending current debates about the expansion of work and workforce into domestic spaces.

There is room in this account to consider two themes from a number that have arisen in a mainly qualitative research study of mother-business owners. The first is the role of the domestic neighbourhood in providing the resources necessary for business formation within family-embedded daily time-space routines. The second, arising from the first, is the role and nature of business networking within such family-embedded contexts . The stimulus for this study arose from a personal conversation in a school playground. A fellow mother revealed that she had just started a new internet-based travel agency business that had been inspired by her experience of holidaying with her toddler. She reported that it was doing unexpectedly well, in fact, almost frighteningly well. She called herself a "Mumpreneur". She needed extra labour for this growing business, did I know anybody with appropriate skills and time to spare, perhaps one or two of my students? I started to think; new business, innovative thinking, growing, being negotiated and recruiting at the school gate. Was this a common but under-studied type of entrepreneurship in an under-studied location?

This thought was timely. In a recent special issue of Entrepreneurship and Regional Development, the Editors, Steyaert and Katz (2004) gave consideration to how we should conceive entrepreneurship as a societal rather than an economic phenomenon (the latter having accounted for the bulk of interdisciplinary entrepreneurship studies and theory building to date - Steyaert and Katz (2004)). The conclusions they reached were that entrepreneurship researchers need to expand their definitions about what 'entrepreneurship' is, and look to new spaces and places for entrepreneurship activity. Such argument seeks to remind scholars that entrepreneurship happens in the sphere of life, not just within the limited sphere of the economic (Hanson 2009; Oberhauser 2002; Aspaas 2004; Jennings and McDougald 2007; Jack et al 2002; Aldrich and Cliff, 2003). Highly embedded in routines of daily life, 'mother-entrepreneurs' enable us to explore the basis for such claims. This investigation sets out an agenda for future research on gender and entrepreneurship, new economic activity in domestic spaces and by extension, professional women's work biographies.

\section{Further background}

There has been significant interest, policy and academic, in women's entrepreneurship. In the United Kingdom, very small businesses account for a vast proportion of enterprise (seventy three per cent of all UK enterprises have no employees and seventeen per cent of these, are managed solely by women (Harding 2006)). UK female entrepreneurship is a significant economic and social phenomenon and it is increasing (this is true for other countries too (McClelland et al 2005)), especially in rural areas (Harding 2006). Accordingly, U.K. policy makers are aware that female entrepreneurship offers some solution to the problems of the loss to the economy of highly skilled female labour as a result of family formation (The UK Women's Enterprise Task Force was set up in 2005 as a response to this). Research also indicates that women's businesses are often different to men's in terms of their nature, location, 
type and the way that business is done (Harding 2007; Ahl 2006; Hanson 2003; Hanson and Blake 2005), but it has been argued that women's participation in entrepreneurship, and indeed self-employment generally, is under-theorised (Blake 2006; Ahl 2006; Lewis 2006) and undifferentiated (Ekinsmyth under review).

Part of the reason for this under-theorisation, it is argued, is that the research that does exist on female entrepreneurship tends to be based upon extensive research using large-scale databases rather than detailed, intensive research designs (Aldrich and Cliff 2003). Referring back to Steyaert and Katz's (2004) propositions, it is difficult to uncover the societal dimensions of entrepreneurship through large-scale economicindicator based surveys. In order to discover new things about entrepreneurship, we need to be asking different questions of different people in different places. Aware of this, Aldrich and Cliff (2003) advocate the adoption of a 'family embeddedness approach' to female entrepreneurship; Moen and Sweet (2004), advocate a 'life course approach'; and several authors call for a gendered and/or feminist approach to the subject (for example; Berg 1997; Bird and Brush 2002; de Bruin et al 2007; Hanson 2003; Ahl 2006; Mirchandani 1999; Bruni et al 2004; Buzar et al 2005). Having adopted a gendered approach, Hanson (2009) argues that we need to acknowledge the importance within entrepreneurship, of networks of social relations in place. What each of these approaches have in common is an acknowledgement that entrepreneurship as a process does not happen (solely within an economic realm) in isolation to the rest of life. Entrepreneurial decisions are taken within context; societal, geographical, familial. Steyaert and Katz talk about "(R)ethinking the boundaries of entrepreneurial spaces" (p184). As part of this, we also need to re-think the boundaries of entrepreneurial processes so that the all-so-important half-conversations in places like school gates also become the focus of entrepreneurial studies. As de Bruin et al (2007) argue: "What researchers frequently neglect in entrepreneurship research is the embeddedness and context specificity of entrepreneurship. .... We believe this [also] results from dominant research approaches, which focus on "clean" databases and up-to-date statistical techniques instead of the messy "real-life" variety of entrepreneurship..." (de Bruin et al 2007, 331).

Inspired both by the women's stories and arguments in the literature, the research project that this paper reports, aimed to explore the circumstances of a subgroup of female entrepreneurs who operate at the interface between paid work and motherhood, and who are creating for themselves, I contend, a sub-culture of entrepreneurship. Problematically labelled in the press as 'Mumpreneurs' (and more appropriately labelled 'family-embedded entrepreneurs' (Ekinsmyth forthcoming, 2011)), I argue here that such women are engaged in a new type of business practice, one that departs in varying ways from masculinist norms of entrepreneurship. Embracing, rather than damage-limiting the role of 'mother', such business practices attempt to recast the boundaries between productive and reproductive work.

\section{Methods}

The research project involved the detailed study of a group of entrepreneurial mothers as a way to uncover some of the "non-obvious", personal, "messy" and perhaps more "silent" processes involved in entrepreneurship, a research focus that the literature has increasingly argued is necessary (Steyaert and Katz 2004; de Bruin et al 2007). In order to present detail of the research cases in limited space, this paper focuses upon two indicative businesses, but the themes that emerge from these cases were common for the 
other businesses included in this project and, as previous research has suggested, other similar businesses in the U.K. and abroad (see for example Blake 2008; Hanson 2009; Oberhauser 2002). They are important themes that require attention because there is a great deal of this kind of entrepreneurial activity occurring (Harding 2006). Additionally, as Hanson (2009, 262) argues, such activities are "changing the structures of opportunity in places". Large-scale surveys of small firms do not necessarily capture these entrepreneurial activities and certainly do not capture their detail.

A mixed-method approach was taken. First, and most significantly, twenty-eight mother-entrepreneurs were interviewed, chosen as cases through a combination of snowballing and cold calling. This method enabled the inclusion of micro entrepreneurs in a breadth of sectors, some of which would not have been recruited by more formal case-selection procedures. In-depth interviews were conducted with each businesswoman, either face-to-face, or, for the more geographically distant, by telephone. Interviews lasted between forty minutes and two-hours and lines of discussion focused around the business (decisions to start-up, size, networks and networking, location and accommodation, employees and recruitment, outsourcing, marketing, future strategy, aspirations), family (including work-life balance, attitudes to motherhood, problems), home (size, demands made by), educational and working history. Two interesting cases were followed up 12 months after the first interview. A grounded theory approach using thematic analysis of the interview transcripts was enacted.

Table 1: Business types of interviewees and questionnaire respondents (N.B. Some respondents had more than one business.)

\begin{tabular}{|l|c|}
\hline Business Type & All respondents \\
\hline Personal services, PA training and PR & 11 \\
\hline Baby and children's products & 13 \\
\hline Website design/ IT consultancy & 3 \\
\hline Writing, Blogging, Art and design & 7 \\
\hline Travel and tourism & 2 \\
\hline Network marketing consultancies & 8 \\
\hline Events management & 3 \\
\hline Online or other networking forums & 4 \\
\hline Inspirational speaking/ consultancy & 3 \\
\hline Therapy services & 4 \\
\hline Children's activities & 3 \\
\hline Selling non-children products & 9 \\
\hline
\end{tabular}

Second, to broaden the range of individuals in the research, data was gathered by way of a questionnaire, from thirty-nine delegates (out of sixty) at 'The Mumpreneur Conference 2009', held in Birmingham, UK. All interview and questionnaire respondents were aged between 27 and 50 and were educated to at least degree level. All had spent time in professional jobs before parenthood and all but three, were living with a partner and child(ren). All interviewees worked at or from home. Business types were various, many were orientated towards the children's and parenting markets, but many were not (Table 1). Cases were spread across England (with a concentration of interviewees in the south-east) and one respondent lived in France. Results are specific 
to the U.K. but evidence from studies of women's entrepreneurship suggests applicability across other national contexts.

\section{Domestic neighbourhoods and families as business context.}

There is space in this paper to consider only two aspects of these businesses, the domestic neighbourhood as an 'unconventional space' for entrepreneurship, and the 'business' networking that occurs as a by-product of family activity as an 'unconventional business practice' . In order to deal here with the detail that reveals the fullest picture, key themes are exemplified through the cases of Alice and Sharon . These cases have been chosen because of the particular clarity with which they illustrate the processes, situations and practices of family-embedded entrepreneurship evident throughout the wider group.

\section{Alice - Head lice treatments and combs}

Alice was contacted after a product was purchased with these words on the packaging:

"As Mums we have all been through 'head-lice hell' ourselves, and we will do anything we can to help any family stay Nit free.

The Lice-Free Mums”

The implication here is that the buyer can trust the product because the business is owned by real-life Mums. And indeed, this motherhood-related problem of head-lice was the breeding ground for the business. Repeated school gate conversations between three women from different working and skill backgrounds (a photographer, aromatherapist and an employee of The Body Shop) revolved around the problems that their daughters were having with head-lice:

"We were three mums with a lot of children between us and we constantly had a problem with nits. We had nothing to do with nits before, one of us was a manager of a body shop branch, my daughter's best friend's mother did aromatherapy and massage and she came up with a couple of concoctions .... And one day she came up something that really did get on top of them ... and my daughter said, I think this has worked, you should think about making this and selling this to the other mums. We had a laugh and then thought about it and ..."

"We asked Gemma who was another close friend and we asked, do you have people coming into the Body Shop and asking for natural cures for nits and she said, well yes, actually we do but we don't make anything - so then we said we are thinking of marketing this stuff, what do you think? Do you want to come into business with us? And that is basically how we started, it really was kitchen sink. Gill got a load of bottles from the Body Shop and we made it up ourselves and we gave it out to our friends and said, you know, try this, see what you think and we decided to really give it a go. So we all put in a very small amount of money - just literally enough to buy some bottles and stock um and we really thought we would just do it by word of mouth in our local school."

Alice described a process of happenstance, experimentation and snatched, partial conversation/networking amidst child-related activities. These 'conversations' had taken place at the school gates, in the neighbourhood park and at children's activity drop-offs and pick-ups. The decision to start the business was hatched slowly, they had discussed 
it for some time before they took steps, carried out research and discussed other ideas for businesses. The impetus for this new business was a combination of interest, desire to work with one's friends and desire to earn extra money. For Alice, a photographer who, at the start of the business in 1999 was unhappy with the agency she worked for, the impetus was for extra income ("A little something to subsidise the photography for me”) and time/space flexibility:

"It was much easier to be self-employed and do something that suited yourself"

By the time the business was launched, Alice's children were teenagers and, as the bread-winner for the family, she was motivated by extra income but did not expect (or desire) it to take over as her major income source. Their beginnings required long hours for little financial return and they started with few resources, using Alice's apartment as their office, factory and warehouse:

"We put in $£ 500$ each to buy the initial stock and take a couple of ads. We worked for no wages for a long time. We were working full time but not taking any money. Gemma was OK as she was supported by her husband and didn't need a huge wage."

They had no help from business start-up agencies, advisors or funders:

"We went to the Portabello Business centre just after we started and actually they were not helpful at all .... We seriously did muddle through ... and I say that often and X tells me off and says you wouldn't have the business you have if you had muddled through .. but we did .... If we had known what we were getting into .......... I really don't think I would do it now if I knew what I was getting into ”

This point is interesting and common amongst the wider interview group. Alice believed that she wouldn't have started the business if she had appreciated the effort involved. In this case, the business required an element of business naivety on the part of the women involved. Research on well-researched, traditional business launches would perhaps miss this necessary precondition. Alice seemed amazed that the business has worked:

"When I think of some of the things we did, it is amazing that we have got this far...."

The conversations about networking with Alice seemed to emphasise happenstance and social/ friendship-based networks. She was passionate when she spoke about the community of mothers in her neighbourhood and their role in her (business) life:

"We had a fantastic network of parents - right from playgroup - a lot of the mums were working in something or other and we really mucked in and looked after each other's children so we were really, really lucky - we were always in others' houses and there was never any bad feeling - the children had a really unique London childhood - it was partly because we lived next to Holland park and you went to the playground and you could go up there at any time of day and you would bump into someone you knew and you could ask - could you look after the children?" 
"We all live within 2 minutes of each other, all our daughters went to the same primary school and Gill and I went to the same secondary school but didn't really know each other then. We have all been there for practically forever. Our daughters went to play group together since they were two and they are still best friends."

Thus the degree of local rootedness and embeddedness for the business partners was high and significant. Not in any kind of formal business sense, but in the sense that this local neighbourhood embeddedness and society had spawned a creative partnership and led to the creation and growth of a successful business. The three business partners had worked at, and worked out, the business together ("everything was trial and error") with no formal help. Eight years after starting up, they had their products on the shelves in Boots the Chemist and Sainsburys, they had joined forces with inventors of a head-lice comb from Argentina ("two Dads" - a union Alice describes as "just fate") and had added these to their product range. They had an arrangement with a small aromatherapy company to produce and bottle the product who they had met in their first year at a trade fair. One of the original women owners was now doing little for the company and the other two had been joined by a male business partner (a local "Dad"). Alice reported being rather scared of expansion and reluctant to employ people outside of her social network circle:

"There are only 3 of us - there are not enough of us - we are actually a bit scared as we are going to have to start employing other people.... ...we are talking about using people we know at the moment."

Whilst strongly rooted in the social neighbourhood networks, the business was not rooted in networks of other businesses ("We have stuck (for manufacture and bottling) with the same people who we met at a trade fair by accident"), most of their work (accountancy, PR), they performed themselves rather than out-sourcing it. When attempting to understand some of rationale for the decisions that drive the business and its future, it is important perhaps to be reminded (as Alice says she has to remind people who want to give her advice) of the following:

"One of the reasons we have gone into business is that we don't want to be a big, big company that's got all these commitments. We want to do it in our own time, expand when we want and not necessarily be doing every single thing we possibly can just to make more money ...."

Thus there are many unconventional entrepreneurial processes and factors coming to play in this business. Happenstance, business naivety, friendship, the sharing of a parenting-related problem, having time to experiment with a new idea, having a shared vision with friends, a particular attitude to motherhood and gender roles, local embeddedness and under-utilized human capital all contributed to the building of this business. The other businesses in this study revealed similar sets of key factors. In the following section, a second example is presented which demonstrates the similarity in the themes and processes that emerged during a long conversation with the business owner of a children's music group/ training/music provider. 


\section{Sharon - Young children's music groups and education.}

Since 2002, Sharon and her business partner have created (first interviewed in 2007) a business that produces and delivers young children's music workshops, and training and materials to teachers. One of the partners writes the music and had started to use it in 'mother and toddler' music sessions in her local area of South West London. My interviewee had attended one of these groups with her two small children, and when she relocated to another part of the country (having given up her job as a high-powered business executive to spend more time with her family), decided to ask her friend if she could use the music to deliver sessions herself in her new area. The business had grown and developed from this into an enterprise that provides teacher training and music/literacy materials for early years teachers in schools in several UK Local Education Authorities, as well as mother and toddler sessions in two local areas. The geographical nature of delivery means that there is vast potential for geographic and thus, business expansion.

As the following quotes from Sharon show, the business had almost come about accidentally and most certainly as part of a process of prioritising family life over that of a high-powered career:

"When I started it was literally a hobby because when we moved to Ringmouth, I had just given up my career (as an accountant) ... I was working really long hours and I was in America a lot and we had two boys at that stage ... and we decided we would have to change ... we had had a full-time nanny and I just felt like life was running away and I just wasn't happy with that situation...”

"I had taken the babies to SingTots in Wandsworth and I got very friendly with Halle - I just hit it off with her and I love her music - I knew there was something really special about it and, when I came here, I looked for music groups for the children and went to a couple and just thought they were dire ... and I don't know what motivated me to do it but one day I just phoned Halle and said how would you feel about me using some of your songs and starting a group up here because there was nothing ...”

Sharon used the word 'hobby' several times to describe her thinking at this stage. She was looking for something interesting to do and felt that she would enjoy running Halle's classes. Sharon was also aware that Halle had created a format that could be very successful if she had more time to develop it more formally:

"She [Halle] has always worked absolutely flat-out, lots of classes around SW London and SingTots is just a little of what she does ... she was a single mother with 2 young children back then, they were young, she struggled and struggled and never made much money but I knew she had an amazing talent ... writing fantastic music and she said yeah - great - go for it - we emailed each other, she sent me some of her workshop plans and I started one at the Cathedral, and just invited some of my NCT friends along and immediately they loved it and I thought I could do another one of these and I set it up at Eastley ... but it was only ever to be an in-between hobby ........ then we got work for Family Learning [a government agency providing classes through schools for parents in parenting skills] ... and they started to recommend us to the Early Years Service." 
The combination of Sharon's business and organisational skills (formerly a highachieving marketing executive) and Halle's creative skills produced a winning formula, but as the above discussion shows, it was happenstance, family-embeddedness and neighbourhood life and social networking that spawned this business. The potential of the business now is now becoming apparent to Sharon, but she was aware of her need to keep the brakes on growth and to keep the business manageable and in-line with her original work-life priorities:

"I know that, potentially, the business could grow much quicker but we both feel, it is not like we are going to miss the boat of we don't go for it now .... I don't let it frustrate me because I remember that I took this job so I wouldn't get stressed and it wouldn't take over my life because I want to spend time with the children .. but Halle's very like me, she's not go-go-go"

"I wouldn't want to advertise for licensees... At the moment we couldn't support any wider expansion and I feel very much more comfortable with people I know as I have built up a personal relationship before we start working with them, so we are sticking with that at the moment."

Indeed, in common with Alice above, Sharon had always recruited employees and licensees through channels of friendship networks revolving around the children and their activities:

"Kate who is now in the IOW was the first one to work with me .... First I had Kate .. she set up a group in Bafton and somewhere else (where did you meet her?) she was a Mum, she's got Isobel who is the same age as Emily- they were at St $J$ Nursery together ...and she's very musical and she was a nursery nurse ... she felt it was something she would like to do... and in fact she brought Isobel to my group at the Cathedral and it was the two of us for 18 months - (an aside) Kate was a friend of Sandra's as well um, oh yeah, that's how we got Sandra in on it - Sandra started to do a bit- and then obviously Sandra got involved in going back to her OT work, Kate moved to the IOW but now I've got Tracey who is fantastic, she is really good at it .. again she thought she would only do it for a year and then go back to Nursing but I think she's found that it fits in with her life and she enjoys it as well and she has been with me for a couple of years now I think...”

Through business activities like this, these entrepreneurs can provide employment for similarly positioned women in the local area. The impact of such activities in a local neighbourhood needs to be better understood.

\section{Conclusions}

There has not been space in this paper to engage with many of the debates that are relevant to this subject (see Ekinsmyth 2011). However, the two cases provided here highlight a number of more general themes in an area that has been under-researched by entrepreneurship scholars and those interested in home/work permeability. There is a new and important agenda contained within the stories of these women. Business creation, embedded in family spaces and borne out of desire to manage work/life tensions is a growing phenomenon, increasingly made possible by information and communication technologies that expand the boundaries of business possibility to new 
demographic groups and new geographical spaces. Governments acknowledge potential here but show little signs of understanding the phenomenon enough to invest in effective interventions. The agenda is as follows :

First, we need to understand better the nature and potential of everyday neighbourhood and family spaces to provide the seed-beds for new business formation. This account has shown that good business ideas are born and nurtured in the everyday, mundane spaces of family life and can come to fruition through networking occurring in these spaces. Recruitment too, is happening this way. Almost overwhelmingly, the entrepreneurs were turning to their social contacts and networks as channels of staff recruitment when needed. This word-of-mouth operation was seen to be less risky than formal channels, cheap and capable of supplying colleagues who would be reliable, easy to manage and (often) geographically proximate. Here school gates, children's play spaces and clubs, churches and other community spaces become arenas for entrepreneurial imagination, action, recruitment and job creation.

Second, we need to extend the boundaries of legitimate entrepreneurial identity. Successful new business identities can emerge out of motherhood and through the (often painful) negotiation of identity that professional women manage with the advent of motherhood. Within the family context, happenstance, as well as formal, "rational economic" decision-making can be key to understanding the creation, growth and development of business. Fortuitous meetings and friendships can lead to new ideas and experiments. This research found that highly skilled and educated women, stepping out of the formal labour market, were forming friendships around their children within children's activity spaces, and businesses were being born as a result. Aldrich and Cliff (2003) argue that major life transitions like parenthood can lead to the identification of new market niches. These findings evidence this claim. Temporary coalitions of skilled people (mothers, parents), who are similarly making life transitions, can, and do provide the breeding ground for innovation and creativity. Economic geographers must therefore redirect some of their focus from innovative clusters in cities and business parks to those occurring in communities, family and domestic spaces. A new research frontier in the areas of business formation and local economic growth is required. And from a policy perspective, we need to understand how best to ensure that mundane family and neighbourhood spaces provide the breeding ground, support and resources necessary for entrepreneurial imagination, new business formation and local economic growth.

\section{References}

Ahl, H. (2006), 'Why research on women entrepreneurs needs new directions', Entrepreneurship: Theory \& Practice 30:5, 595-621.

Aldrich, H. and Cliff, J. (2003), 'The pervasive effects of family on entrepreneurship: toward a family embeddedness perspective', Journal of Business Venturing 18, 573596.

Aspaas, H. (2004) 'Minority women's microenterprises in rural areas of the United States of America: African American, Hispanic American and Native American case studies', Geojournal 61, 281-289.

Berg, N. (1997), 'Gender, place and entrepreneurship', Entrepreneurship and Regional Development 9, 259-268.

Bird, B. and Brush, C. (2002), 'A gendered perspective on organizational creation', Entrepreneurship: Theory \& Practice 26, 41-65. 
Blake, M. (2006), 'Gendered lending: gender, context and the rules of business lending’, Venture Captial, 8:2, 183-201.

Blake, M (2008), It Takes a Village: Women's Entrepreneurship, Resource, Networks, and Place (Saarbrucken: VDL Verlag Dr. Muller Aktiengesellschaft \& Co. KG).

Bradley, H. (2007), Gender, Polity Press, Cambridge.

Bruni, A. Gherardi, S. and Poggio, B. (2004), 'Doing gender, doing entrepreneurship: an ethnographic account of intertwined practices', Gender, Work \& Organization 11, 406-429.

Buzar, S. Ogden, P. and Hall, R. (2005), 'Households matter: the quiet demography of urban transformation', Progress in Human Geography 29, 413-436.

de Bruin, A., Brush, C. and Welter, F. (2007), 'Advancing a framework for coherent research on women's entrepreneurship’, Entrepreneurship: Theory \& Practice 31, 323339.

Ekinsmyth, C. (2011), 'Challenging the boundaries of entrepreneurship: The spatialities and practices of UK 'Mumpreneurs', Geoforum, Vol. 42, pp.104-114.

Ekinsmyth, C. (2012), 'What is in a name? The 'mumpreneur' debate and contemporary feminism', Enterprising Matters, Institute of Small Business Economics (ISBE), Winter 2012. www.isbe.org.uk/The-mumpreneur-debate-and-contemporary-feminism

Hanson, S. (2003), 'Geographical and feminist perspectives on entrepreneurship', Geographische Zeitschrift 91, 1-23.

Hanson, S. and Blake, M. (2005), 'Changing the gender of entrepreneurship', in L. Nelson and J. Seager (eds), A Companion to Feminist Geography (Oxford: Blackwell). 179-193.

Hanson, S. (2009), 'Changing places through women's entrepreneurship', Economic Geography 85:3, 245-267

Harding, R. (2006) GEM Full Report (London: London Business School).

Harding, R. (2007) State of women's enterprise in the UK Norwich: Delta Economics. Prowess Limited).

Jack, S. and Anderson, A. (2002) 'The effects of embeddedness on the entrepreneurial process', Journal of Business Venturing 17, 467-487.

Jennings, J. and McDougald, M. (2007), 'Work-family interface experiences and coping strategies: Implications for entrepreneurship research and practice', Academy of Management Review 32, 747-760.

Lewis, P. (2006), 'The quest for invisibility: female entrepreneurs and the masculine norm of entrepreneurship', Gender, Work \& Organization 13, 453-469.

McClelland, E., Swail, J., Bell, J. and Ibbotson, P. (2005), 'Following the pathway of female entrepreneurs', International Journal of Entrepreneurial Behaviour and Research 11:2, 84-107.

Mirchandani, K. (1999), 'Feminist insight on gendered work: new directions in research on women and entrepreneurship', Gender, Work \& Organization 6, 224-235.

Moen, P. \& Sweet, S. (2004), 'From 'work-family' to 'flexible careers' Community, Work \& Family, 7:2, 209-226.

Oberhauser, A. (2002) 'Relocating gender and rural economic strategies', Environment and Planning A 34, 1221-1237.

Steyaert, C. and Katz, J. (2004), 'Reclaiming the space of entrepreneurship in society: geographical, discursive and social dimensions', Entrepreneurship \& Regional Development, 16:3, 179-196. 